(К3 "Житомирський обласний інститут післядипломної педагогічної освіти"

Житомирської обласної ради) harchenko-2@ukr. net

ORCID: $0000-0002-3083-2612$

\title{
ТЕОРЕТИЧНІ ЗАСАДИ ПІДГОТОВКИ УЧИТЕЛІВ ОСВІТНІХ ЗАКЛАДІВ ДО ФОРМУВАННЯ КОМУНІКАТИВНОЇ КОМПЕТЕНТНОСТІ УЧНІВ
}

У статті розглядаються особливості реалізації комунікативного підходу в контексті модернізації украӥнської системи освіти та ї̈ інтеграиії в європейський освітній простір. Автор виділяє особливості комунікативної діяльності вчителів освітніх закладів, визначає соиіокультурні, педагогічні та інформаційно-технологічні передумови формування комунікативної компетентності школярів. Проаналізовано сутність комунікативної компетентності в межах сучасної мовної політики, впровадження компетентнісно орієнтованих освітніх стандартів, розробки комунікативного освітнього простору навчального закладу та проектування змісту мовної освіти на основі інтеграції та індивідуальної мотивації навчання.

Ключові слова: спілкування, компетентнісний підхід, комунікативний підхід, комунікативна
компетентність, комунікативна діяльність, комунікативна культура, освітній простір.

Постановка проблеми у загальному вигляді. Проблема комунікативної компетентності є актуальною, оскільки від рівня її розвитку залежить не тільки соціальна сфера школяра, але й успішність у спілкуванні та навчанні. Формування комунікативної компетентності в освітньому закладі $є$ одним 3 пріоритетних завдань сучасної освіти, що відображено в державних документах, зокрема в Національній стратегії розвитку освіти в Україні на 2012-2021 рр. наголошується на необхідності переходу від суспільства знань до суспільства життєво компетентних громадян. Підготовка сучасного вчителя передбачає формування професійно-педагогічної комунікативної компетентності, яка виступає як чинник особистого розвитку і як зміст освітнього процесу, в якому професійна компетентність учителя, його гуманність, щирість, повага до учня відіграють головну роль. Імплементація основних положень в державних документах (Законах України "Про освіту", "Про вищу освіту", Національній рамці кваліфікацій (постанова Кабінету Міністрів України від 23.11.2011р.), Концепції впровадження медіаосвіти в Україні, Загальноєвропейських Рекомендацій з мовної освіти), передбачає удосконалення організації освітнього процесу в освітніх закладах, формування національно-мовної особистості, яка володіє усним і писемним словом [1]. У документах приділено увагу проблемам формування комунікативної компетентності школярів, зокрема вмінь самостійно приймати відповідальні рішення, прогнозувати їх можливі наслідки, адаптуватися відповідно до динамічних змін сучасного світу; умінь вільно, комунікативно виправдано користуватися мовними засобами під час сприйняття та створення висловлювань у різних формах, стилях й жанрах мовлення; а також проблемам дослідження комунікативної функції мови, яка забезпечує мовленнєву діяльність особистості, основну передумову для формування комунікативної компетентності.

Важливою тенденцією реформування системи освіти $є$ поглиблення й ускладнення зв'язків у сучасному глобалізованому світі, адже комунікативні відносини як між країнами, так і в міжособистісній взаємодії актуалізують потребу формування "людини комунікації" [2], особистості, яка має активну суспільну позицію, критичне мислення, поведінку, вміє грамотно взаємодіяти з оточуючими людьми, погоджувати свої дії, адекватно діяти в будь-яких життєвих ситуаціях освітнього й суспільного середовища.

Зв'язок із важливими науковими і практичними завданнями. У філософській, психологічній та педагогічній літературі накопичено значний досвід підготовки вчителя до комунікативної діяльності в навчально-виховному процесі освітнього закладу, зокрема проблему педагогічної взаємодії, педагогічної комунікації в контексті професійної діяльності вчителя розглядали О. Березюк, І. Бех, А. Бодальов, Г. Васьківська, О. Власенко, С. Гончаренко, О. Дубасенюк, В. Кан-Калік, В. Сухомлинський та ін.; компетентнісний підхід, структуру комунікативної компетентності, комунікативну культуру вчителя, комунікативні уміння й навички досліджували Н. Бібік, І. Зимня, В. Краєвський, В. Кремень, О. Локшина, О. Пометун, Ю. Рибалко, О. Савченко, А. Хуторський та ін.

Мета статті полягає у теоретичному обгрунтуванні процесу підготовки сучасного вчителя до формування комунікативної компетентності школяра.

Розглянемо базові поняття. У вітчизняних та зарубіжних дослідженнях в процесі дослідження формування комунікативної компетентності, комунікативну компетентність визначено як якість особистості, що інтегрує в собі особистісні комунікативні якості (цінності, потреби, мотиви), знання про систему мови, володіння мовними поняттями й засобами, культурою спілкування як у соціальному житті, так і у професійній сфері [3]. Адже культурно-комунікативною основою будь-якого суспільства в цілому, і 
українського зокрема, є міжособистісні взаємини, що реалізуються в процесі спілкування та формуються під час навчання, виховання й професійно-практичної підготовки. Комунікативна компетентність виступає інтегративною особистісною характеристикою, яка передбачає засвоєння певної суми предметних знань про світ, використовуючи інтелект, мобільне мислення, толерантну поведінку, адаптивні форми соціокультурної діяльності. Комунікативна компетентність вимагає від школяра швидкого засвоєння інновацій, адаптації до суспільних змін у своїх формах діяльності, характеризується єдністю предметних та метапредметних знань, умінь й навичок, що включають уміння говорити, розуміти, узгоджувати свої дії та думки для створення загального комунікативного простору, а предметні та метапредметні знання забезпечать гармонійне включення в сучасний мінливий світ культури й майбутньої професії. Метапредметний рівень навчальної діяльності визначають навчальні метапредмети - освітні структури, зміст яких групується навколо системи фундаментальних освітніх об'єктів, що є ключовими сутностями, які відображають єдність світу. Це вузлові точки основних освітніх галузей, завдяки яким існує реальна галузь пізнання й конструюється ідеальна система знань про неї [4: 43]. Оскільки мовний та мовленнєвий компонент є головною особливістю практичної діяльності вчителя освітнього закладу, виникає потреба в удосконаленні процесу формування його професіограми [5].

Поняття комунікативна компетентність розглядається науковцями як характеристика особистості, як частина інших видів компетенцій, як індивідуальна якість (І. Когут, В. Куніцина, М. Оліяр та ін.). Відтак мовна й мовленнєва компетенції визначаються необхідною умовою здобуття компетентності в усіх сферах життєдіяльності суб'єкта (А. Богуш, І. Зимня, М. Пентилюк, Л. Скуратівський).

Осмислення педагогічних концепцій, авторських освітніх закладів та програм, зокрема особистісно зорієнтованого навчання, розвивального навчання, педагогіки М. Монтессорі, гуманістичної педагогіки Ш. Амонашвілі, педагогіки взаємного навчання та спільної діяльності, а також інноваційного досвіду педагогів-новаторів В. Дьяченко, Л. Занкова, Д. Ельконіна, В. Давидова, Є. Ільїна, А. Макаренка, Є. Пассова, О. Ривіна, В. Сухомлинського, В. Шаталова, Р. Штайнера, М. Щетініна та багатьох інших, показало, що в концепціях, авторських школах, програмах, як і в масовій шкільній практиці, проблема формування комунікативної компетентності розглядається лише як одне із завдань поруч з іншими.

Аналізуючи досвід роботи учителів освітніх закладів в контексті цієї проблеми, визначили типові труднощі в організації та проведенні уроків, способів реалізації принципів комунікативного підходу, проблематики уроку (мети, змісту, структури, типології, ефективності), з'ясували, що проблема уроку як основної форми навчання лише частково, ситуативно торкається комунікативного підходу [6; 7]. Така ситуація, скоріше за все, викликана відсутністю чіткої технології реалізації комунікативного підходу в освітньому закладі. Очевидно, що провідним завданням учителя освітнього закладу $є$ формування комунікативної компетентності учнів, що, в свою чергу, вимагає від учителя оволодіння певним рівнем сформованості власної професійно-комунікативної компетентності.

У розробці структури досліджуваного поняття за результатами аналітико-синтетичної обробки наукової літератури враховано особливості комунікативної діяльності вчителів освітніх закладів та визначено, що передумовами формування комунікативної компетентності школярів є соціокультурні передумови, оскільки детермінантою комунікативної компетентності особистості є спілкування, що забезпечує гуманні взаємини людини 3 іншими, співіснування, взаєморозуміння та самореалізацію. Педагогічні передумови відображають шляхи модернізації української системи освіти та ії інтеграцією в європейський освітній простір, впровадженням компетентнісно орієнтованих освітніх стандартів, розробки освітнього простору навчального закладу та проектування змісту мовної освіти на основі інтеграції та індивідуальної мотивації навчання. Інформаційно-технологічні передумови пов'язані із використанням комплексу інтерактивних технологій навчання, спрямованих на освітню активність учнів, розвитком інформаційно-комунікаційних форм, методів та засобів навчання та виховання, комп'ютерно орієнтованих педагогічних технологій та електронних освітніх ресурсів.

На основі аналізу соціокультурних, педагогічних та інформаційно-технологічних передумов формування комунікативної компетентності в освітньому просторі навчального закладу виявлено протиріччя між використанням уроку як основної форми навчального процесу та недостатньою розробленістю принципів його організації в межах комунікативного підходу; між усвідомленням необхідності формування комунікативної компетентності учнів і відсутністю у вчителів знань про організацію уроку в межах цього підходу. Характерною особливістю освіти в межах реалізації комунікативного підходу є не стільки підготовка учня до майбутнього життя, тренування інтелекту, скільки створення умов для відчуття та переживання ситуації дитиною в певний момент [8; 9].

Комунікативний підхід в освіті виступає системою орієнтирів, необхідних для діяльності людини в навколишньому середовищі, тому освітній процес повинен забезпечити взаємозв'язок змісту, форм, методів навчання 3 комунікативною стратегією загалом. На рівні реалізації комунікативний підхід в освітньому середовищі навчального закладу має наступні ознаки: розвиток критичного, аналітичного, індуктивного, логічного та ін.. видів мислення; орієнтація педагогічної діяльності вчителя на потреби, мотиви, інтереси та життєвий досвід дітей; створення комунікативного освітнього простору навчального закладу тощо. В цьому 
контексті не можна оминути важливість створення емоційного клімату в учнівському колективі, який забезпечить довірливі, дружні та теплі взаємостосунки між учасниками навчально-виховного процесу.

Розробка комунікативних ситуацій в освітньому процесі навчального закладу - це створення конкретних ситуацій спілкування, які визначають мовленнєву поведінку, способи реалізації комунікативної стратегії та тактики. Комунікативність завжди пов'язана із ситуативністю, тому в процесі викладання мовно-літературних предметів комунікативна ситуація виступає структурно складним методом навчання мови, моделюючи реальні життєві умови спілкування, обставини комунікації та мовленнєві наміри [10: 100]. Реалізація визначених в межах моделювання навчальних ситуацій, суб'єкт-суб'єктного спілкування між учасниками навчального процесу потребує вибору відповідних методів й передбачає використання дидактичних ігор, спільне розв'язання ситуацій. А критерієм вибору методів та прийомів навчання має бути ефективність щодо формування навичок, створення особистісної системи цінностей.

Висновки та перспективи подальшого дослідження проблеми. Підготовка вчителів до формування комунікативної компетентності школярів передбачає організацію освітнього простору навчального закладу в контексті постійної комунікативної взаємодії вчителя й учня як суб'єктів навчально-пізнавальної діяльності та розробку змісту навчальних предметів для практичного оволодіння комунікативною компетентністю.

\section{СПИСОК ВИКОРИСТАНИХ ДЖЕРЕЛ ТА ЛІТЕРАТУРИ}

1. Про затвердження національної рамки кваліфікації : Постанова Кабінету міністрів України від 23.11.2011. № 1341 [Електронний ресурс]. - Режим доступу : http://www/zakon2.rada.gov.ua (Нормативні документи МОН України. Постанова)

2. Когут I. В. Зміст формування професійно-педагогічної комунікативної компетентності в сучасних соціокультурних умовах / І. В. Когут // Проблеми освіти : [наук. зб.] / Інститут інноваційних технологій і змісту освіти МОН України. - К., 2013. - Випуск № 77. - Ч. 2. - С. 75-79.

3. Оліяр М. Комунікативно-діяльнісний підхід як основа формування комунікативно-стратегічної компетентності майбутніх учителів початкових класів / М. Оліяр // Науковий часопис НПУ ім. М. П. Драгоманова. Серія 17 : Теорія і практика навчання та виховання / за наук. ред. акад. В. І. Бондаря. - Київ : Вид-во НПУ ім. М. П. Драгоманова, 2012. - Вип. 20. - С. 141-148.

4. Васьківська Г. О. Метапредметний підхід до формування системи знань про людину як один із принципів сучасного підручникотворення / Г. О. Васьківська // Проблеми сучасного підручника. - Вип. 12. - Пед. Думка, 2012. - C. $42-50$.

5. Лазарєв М. О. Культура педагогічного спілкування як важливий чинник гуманітарного перетворення сучасної освіти / М. Лазарєв // Нові технології навчання : [наук.-метод. зб.]. - К. : ІЗМН, 1997. - Вип. 19. - 296 с.

6. Левченко С. В. Творчо-комунікативна позиція майбутнього вчителя як педагогічна проблема / С. В. Левченко // Scientific Journal "ScienceRise". - 2015. - № 7 / 1 (12). - C. 54-59.

7. Бацевич Ф. Основи комунікативної лінгвістики : [підручник] / Ф. С. Бацевич. - К. : Академія, 2004. -344 с.

8. Рибалко Ю. В. Компетентнісний підхід у науково-педагогічній літературі / Ю. В. Рибалко // Педагогіка вищої та середньої школи. - 2012. - Вип. 35. - 392 с.

9. Вторнікова Ю. С. Структура комунікативної компетентності педагога / Ю. С. Вторнікова // Зб. наук. праць Уманського державного педагогічного університету ім. Павла Тичини / [гол. ред. : М. Т. Мартинюк]. - Умань : ПП Жовтий О.О., 2012. - Ч. 3. - С. 41-48.

10. Березюк О. С. Інноваційні технології у підготовці майбутнього вчителя // Інновації в освіті : інтеграція науки $\mathrm{i}$ практики : [збірник науково-методичних праць] / О. С. Березюк, О. М. Власенко ; за заг. ред. О. А. Дубасенюк. - Житомир : Вид-во ЖДУ ім. І. Франка, 2014. - С. 97-106.

\section{REFERENCES (TRASLATED \& TRANSLITERATED)}

1. Pro zatverdzhennia natsional'noi ramky kvalifikatsii [On the Approval of the National Qualifications Framework] : Postanova Kabinetu ministriv Ukrainy vid 23.11.2011. № 1341 [Resolution of the Cabinet of Ministers of Ukraine from 23.11.2011. № 1341] [Elektronnyi resurs]. - Rezhym dostupu: http://www/zakon2.rada.gov.ua (Normatyvni dokumenty MON Ukrainy. Postanova)

2. Kohut I. V. Zmist formuvannia profesiino-pedahohichnoi komunikatyvnoi kompetentnosti $v$ suchasnykh sotsiokulturnykh umovakh [Contents of Formation of Vocational and Pedagogical Communicative Competence in Modern Socio-cultural Conditions] / I. V. Kohut // Problemy osvity [Problems of Education] : [nauk. zb.]. - Instytut innovatsiinykh tekhnolohii i zmistu osvity MON Ukrainy. - K., 2013. - Vypusk № 77. - Ch. 2. - S. 75-79.

3. Oliiar M. Komunikatyvno-diialnisnyi pidkhid yak osnova formuvannia komunikatyvno-stratehichnoi kompetentnosti maibutnikh uchyteliv pochatkovykh klasiv [Communicative-activity Approach as the Basis for the Formation of Communicative-strategic Competence of Future Teachers of Elementary School] / M. Oliiar // Naukovyi chasopys NPU im. M. P. Drahomanova. Seriia 17 : Teoriia i praktyka navchannia ta vykhovannia [National Pedagogical Dragomanov University Journal. Series 17 : The Theory and Practice of Education] / za nauk. red. akad. V. I. Bondaria. - Kyiv : Vyd-vo NPU im. M. P. Drahomanova, 2012. - Vyp. 20. - S. 141-148.

4. Vaskivska H. O. Metapredmetnyi pidkhid do formuvannia systemy znan' pro liudynu yak odyn iz pryntsypiv suchasnoho pidruchnykotvorennia [Metaprime Approach to the Formation of a System of Knowledge about Mankind as One of the Principles of Modern Textbook Creation] // Problemy suchasnoho pidruchnyka [The Problems of a Modern Schoolbook].- Vyp. 12. - Ped. Dumka, 2012. - S. 42-50. 
5. Lazariev M. O. Kul'tura pedahohichnoho spilkuvannia yak vazhlyvyi chynnyk humanitarnoho peretvorennia suchasnoi osvity [The Culture of Pedagogical Communication as an Important Factor in the Humanitarian Transformation of Modern Education] / M. Lazariev // Novi tekhnolohii navchannia [New Technologies of Education] : [nauk.-metod. zb.]. - K. : IZMN, 1997. - Vyp. 19. - $296 \mathrm{~s}$.

6. Levchenko S. V. Tvorcho-komunikatyvna pozytsiia maibutnoho vchytelia yak pedahohichna problema [Creative and Communicative Position of the Future Teacher as a Pedagogical Problem] / S. V. Levchenko // Scientific Journal "ScienceRise". - 2015. - №7 / 1 (12). - S. 54-59.

7. Batsevych F. Osnovy komunikatyvnoi linhvistyky [Basics of Communicative Linguistics]: [pidruchnyk] / F. S. Batsevych. - K. : Akademiia, 2004. - 344 s.

8. Rybalko Yu. V. Kompetentnisnyi pidkhid u naukovo-pedahohichnii literaturi [Competency Approach in Scientific and Pedagogical Literature ] / Yu. V. Rybalko // Pedahohika vyshchoi ta serednioi shkoly [Pedagogy of High and SecondaryS]. - 2012. - Vyp. 35. - 392 c.

9. Vtornikova Yu. S. Struktura komunikatyvnoi kompetentnosti pedahoha [The Structure of the Communicative Competence of the Teacher] / Yu.S. Vtornikova // Zb. nauk. prats' Umans'koho derzhavnoho pedahohichnoho universytetu im. Pavla Tychyny [Collection of Scientific Works of Uman' Pavlo Tychyna State Pedagogical University] / [hol. red. : M. T. Martyniuk]. - Uman' : PP Zhovtyi O. O., 2012. - Ch. 3. - S. 41-48.

10. Bereziuk O. S. Innovatsiini tekhnolohii u pidhotovtsi maibutnoho vchytelia [Innovative Technologies in Future Teachers' Education] / O. S. Bereziuk, O. M. Vlasenko // Innovatsii v osviti : intehratsiia nauky i praktyky : [zbirnyk naukovo-metodychnykh prats'] / za zah. red. O. A. Dubaseniuk. - Zhytomyr : Vyd-vo ZhDU im. I. Franka, 2014. S. $97-106$.

\section{Харченко А. И. Теоретические основы подготовки учителей образовательных учреждений к формированию коммуникативной компетентности учащихся.}

В статье рассматриваются особенности реализаџии коммуникативного подхода в контексте модернизации украинской системь образования и ее интеграции в европейское образовательное пространство. Автор выделяет особенности коммуникативной деятельности учителей образовательных учреждений, определяет социокультурные, педагогические и информационно-технологические предпосылки формирования коммуникативной компетентности школьников. Проанализировань сущчность коммуникативной компетентности в пределах современной языковой политики, особенности внедрения компетентностно ориентированных образовательных стандартов, разработки коммуникативного образовательного пространства учебного заведения и проектирования содержания языкового образования на основе интеграџии и индивидуальной мотиваџии обучения.

Ключевые слова: общение, компетентностный подход, коммуникативный подход, коммуникативная компетентность, коммуникативная деятельность, коммуникативная культура, образовательное пространство.

\section{Harchenko A. I. Theoretical Bases of School Teachers' Training in Forming of Pupils' Communicative Competence.}

The article is devoted to the scientific justification and development of school teachers' training in forming of pupils' communicative competence. It deals with the peculiarities of the implementation of the communicative approach in the context of the modernization of the Ukrainian educational system and its integration into the European educational space. The author analyzes the process of formation of communicative competence in the context of the current Ukrainian language policy, focuses on the communicative approach as the priority and emphasizes on the importance of the relationship between school language education and real needs of our society. The author highlights the peculiarities of the teachers' communicative activity at education institutions, defines socio-cultural, pedagogical and informational and technological prerequisites for the formation of communicative competence of children. The essence of communicative competence in the framework of modern language policy, the introduction of competence-oriented educational standards, the development of the communicative educational space of an educational institution and the content design of language education on the basis of integration and individual motivation of education are analyzed. The author notes that modern communicative focus of the educational process at educational institutions will create opportunities to realize value, development and educational aspects of the Ukrainian language as a school subject. In modern teaching methodology the implementation of communicative approach ensures the creation of a special space for child's education; in which any person choose her own way of activity.

Key words: communication, competence approach, communicative approach, communicative competence, communicative activity, communicative culture, educational space. 